\title{
UTILIZATION OF ADVANCED DIAGNOSTIC METHODS FOR TEXTURE AND RUT DEPTH ANALYSIS ON A TESTING PAVEMENT SECTION
}

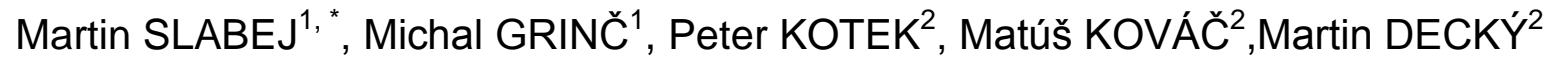 \\ ${ }^{1}$ Research Centre, University of Žilina, Univerzitná 8215/1, 01026 Žilina. \\ 2 Department of Highway Engineering, Faculty of Civil Engineering, University of Žilina, Univerzitná \\ 8215/1, 01026 Žilina. \\ corresponding author: martin.slabej@rc.uniza.sk.
}

\section{Abstract}

Qualitative characteristics of pavement in wide range reflects the pavement serviceability, which is a summary of the characteristics of the pavement, providing a fast, smooth, economical and especially safe driving of motor-vehicles. The target factor of pavement serviceability and safety of roads represents the quality of their surface properties. In the framework of research activities performed in the Research Centre founded under the auspices of University of Žilina, individual parameters of pavement serviceability were monitored by pavement surface scanning. This paper describes the creation of a 3D - road surface model and its analysis and evaluation from the viewpoint of two pavement serviceability parameters - the rut depth and texture. Measurements were performed on an experimental pavement section used contemporary in an Accelerated Pavement Testing experiment. The long-term goal is to ascertain functions predicting degradation of these two pavement serviceability parameters.
\end{abstract}

\section{Keywords:}

Pavement serviceability; 3D scanner;

Profile;

Rut depth;

Texture.

\section{Introduction}

A requirement for quality and safe road infrastructure resonates at present more frequently considering the obligations of EU member states to reduce the number of accidents and fatalities on roads. Pavement diagnostics is, together with the collection of traffic data and updating process of current database of the road network, the main input of pavement management processes. It is the most challenging process of the entire PMS in terms of financial, time, technological and personnel resources. As new technologies arise, they entail not only the simplification the data collection process but also increase in quality of measurement results and even measurement of data which were previously possible to obtain only through destructive methods. The ability to measure more parameters, measure them faster, more accurately and safely, enables us to obtain the desired volume of data needed for complex PMS decision-making processes - estimation of optimal intervention time and choosing of optimal technology for maintenance repair and rehabilitation. This article is focused on the collection of data regarding pavement structure using the interpretation and collection of data regarding the quality of road surface by scanning its surface with a laser beam.

\section{Testing field and measurement equipment}

The test field has a length of 6 meters and a width of 2.2 meters. The pavement structure was designed as a pavement for a road with traffic load class TLC III. It is a flexible pavement with bitumen concrete surfacing. The wearing base layer is made of asphalt concrete (AC) 11; CA 35/50; $40 \mathrm{~mm}$ thick. The base course layer is made of asphalt concrete (AC) $16 \mathrm{P}, \mathrm{CA} 35 / 50 ; 80 \mathrm{~mm}$ thick. The road base is a mechanically bound aggregate MSK $31.5 \mathrm{~GB} ; 180 \mathrm{~mm}$ thick. Sub-base is gravel ŠD; 31.5 (45) GC; $200 \mathrm{~mm}$ thick [7]. 


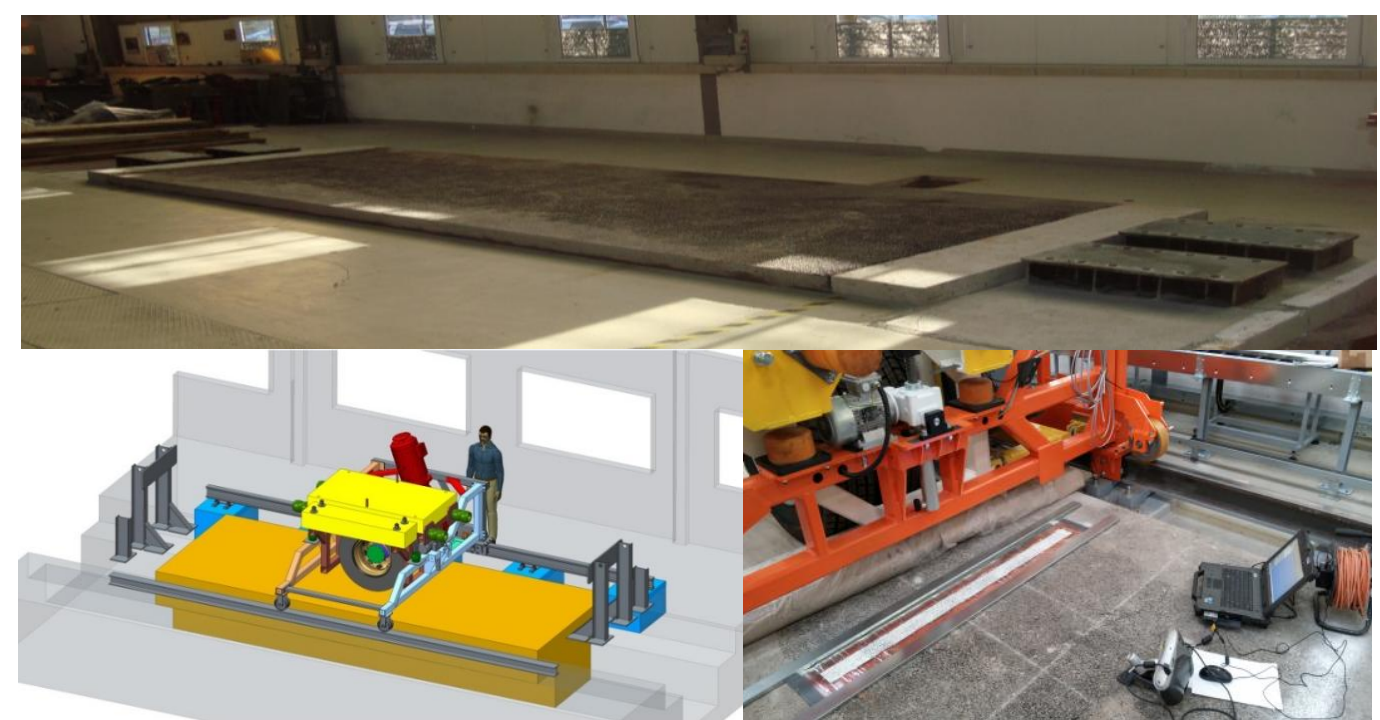

Fig. 1: Accelerated Pavement Testing Facility of the University of Žilina with the loading wheel and design of the facility with the 3D scanner.

The laser scanning technology allows focusing in detail on the pavement surface and it's near surroundings in a coordinate system. In many cases, it is a more detailed measurement than it is provided by other technologies.

Among other advantages of this method a self-moving machine can be included, which does not need any other external mechanisms, that can make a difficulty when scanning remote surfaces and thereby negatively affect the measurement itself [1]. The system allows free movement of the object during scanning.

It is also possible to see an image of the scanned surface in real time. On the test field (Fig. 1), there were realized the measurements using a smaller type of hand-held 3D scanner - ZScanner 800 with a maximum resolution of $0.1 \mathrm{~mm}$. The disadvantage of handheld equipment is time consuming measurement and the evaluation.

\section{Texture}

The texture of pavement surface has a great impact on anti-skid features of the pavement, maybe the greatest. It is the morphological layout of material of the pavement surface. It is usually described by surface profile which is defined by two coordinates. They are a combination of bumps described by wavelength (horizontal projection of bumps) and amplitude showing vertical projection of bumps in terms of given range. The surface texture influences plenty characteristics of car-pavement collaboration including friction by wet weather, noise, water spraying, rolling resistance, tyre wear and damage of the car. They have their special meaning in the skid resistance microtexture and macrotexture point of view [3].

The microtexture reflects tiny prominences on aggregate grains and describes how the grains are smooth or rough and therefore the friction between tyre and pavement surface rises. It is characterized by wavelength range from 0.001 to $0.2 \mathrm{~mm}$ and amplitude range from 0.0 to $0.2 \mathrm{~mm}$ [4]. Due to the range, there is created impression of rough surface but microtexture is usually too soft to recognize it visually. The microtexture of aggregate surface issues elementary friction level and is important on dry surface by low speed up to $40 \mathrm{~km} \cdot \mathrm{h}^{-1}$. Another important meaning lies in an interruption of continual water film and creation direct contact of tyre with pavement surface [4].

Values of microtexture are partially influenced by the ability of aggregates to keep sharp edges and so maintain rough surface which should resist to smoothing caused by truck traffic at longest. The microtexture is partly depended on composition of an asphalt mixture as mineralogical structure of aggregates, max grain size, percentage of small aggregates, and content and type of asphalt binding.

The macrotexture of a pavement surface is responsible for basic drain ability of a pavement. It represents irregularities on a pavement surface and describes a way in which single aggregate grains 
are ordered. It is characterized by wavelength range from 0.25 to $10 \mathrm{~mm}$ and amplitude range from 0.2 to $10 \mathrm{~mm}$ [4]. It is important for fast water diversion from surface of wet pavement because the water acts as lubricant and it shows in the friction between tyre and pavement. Macrotexture plays serious role by middle and higher speeds of vehicle (over $40 \mathrm{~km} . \mathrm{h}^{-1}$ ). A good macrotexture can be get by suitable proposal of aggregates-mortar rate. It can be also achieved with proper combination of methods of final surface modification.

\section{Analyzing of measuring data - 3D scanning}

The scale and accuracy of scanning are important for correct formulation of the requested level of texture and for implementation of scanned data. Scanning with the help of 3D scanner enables formulation of surface in three proportions and therefore complex information about the pavement surface is available.

To compare accuracy of the process, the scanning was done in four resolutions: $2,1,0.5$ and $0.2 \mathrm{~mm}$. The values were selected with a view to potentialities of the device and also to the macrotexture defined above.

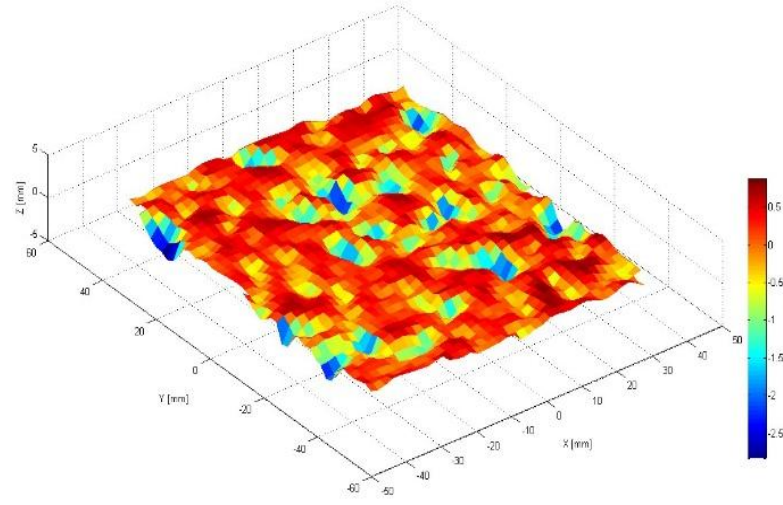

a)

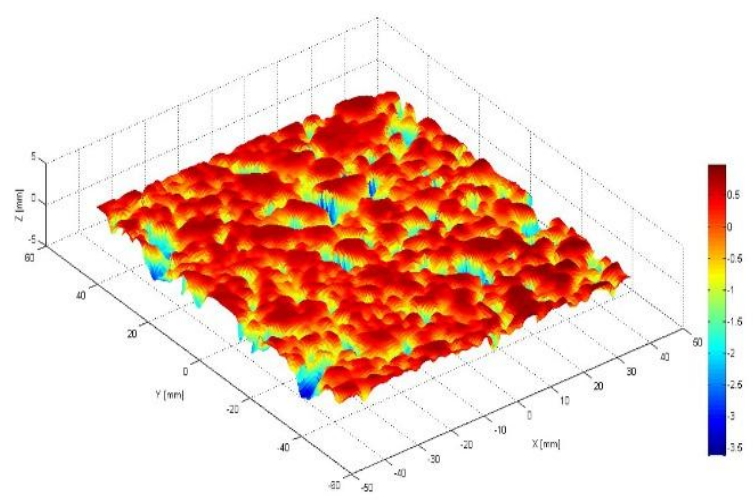

c)

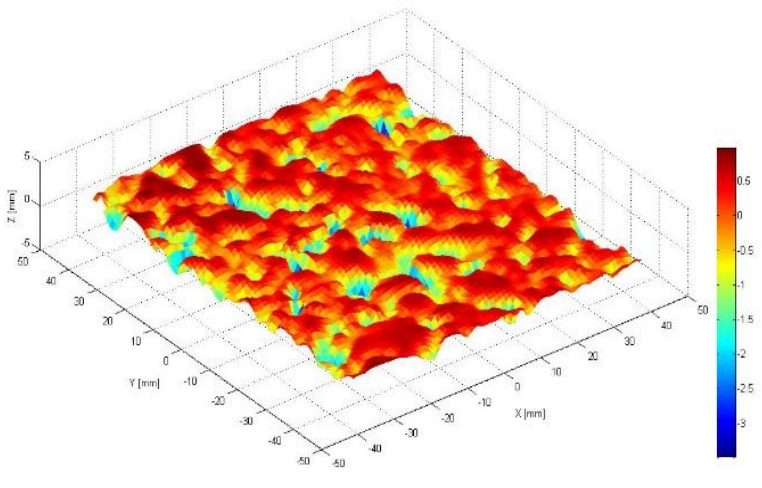

b)

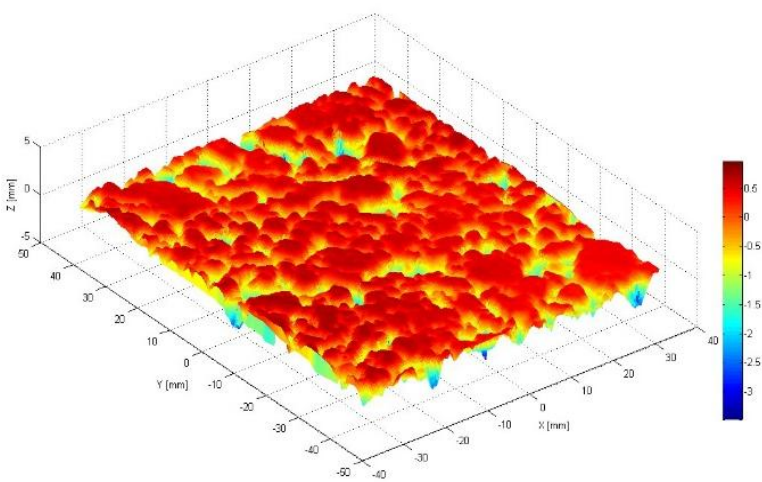

d)

Fig. 2: Pavement surface by the scanning in: a) $2 \mathrm{~mm}$ resolution, b) $1 \mathrm{~mm}$ resolution, c) $0.5 \mathrm{~mm}$ resolution, d) $0.2 \mathrm{~mm}$ resolution.

From the scanned surface can be displayed a profile by an elected resolution. It is clear that increasing accuracy of resolution scanning the profiles show tinier projections. Appropriately chosen scan accuracy is important for further processing of the measured data [6]. 
Based on profiles from measured surface, the mean profile depth (MPD) was calculated and it is used to represent state of surface macrotexture. The values of average depth profile are changing gradually with precision scanning. As the accuracy of scanning was rising, the MPD value also raised.

Table 1: The values mean the profile depth surface.

\begin{tabular}{|l|c|c|c|c|c|c|c|c|c|c|}
\hline Accuracy (mm) & 2 & 1.9 & 1.8 & 1.7 & 1.6 & 1.5 & 1.4 & 1.3 & 1.2 & 1.1 \\
\hline MPD (mm) & 0.604 & 0.612 & 0.619 & 0.627 & 0.634 & 0.642 & 0.649 & 0.657 & 0.664 & 0.672 \\
\hline \multicolumn{8}{|c|}{} \\
\hline Accuracy (mm) & 1 & 0.9 & 0.8 & 0.7 & 0.6 & 0.5 & 0.4 & 0.3 & 0.2 & 0.1 \\
\hline MPD (mm) & 0.679 & 0.686 & 0.694 & 0.701 & 0.708 & 0.716 & 0.732 & 0.748 & 0.764 & 0.780 \\
\hline
\end{tabular}

The scan unevenness is sufficient to scan at a lower resolution, seeing that the transverse unevenness is in the order of millimeter values. Scanning of cross section with a length of 1.6 meters and a width of $8 \mathrm{~cm}$ was realized with the scanning resolution accuracy of $1 \mathrm{~mm}$. For better determination of analyzed profile and mainly due to the relatively difficult lighting conditions, there are used the bounding observed cross section in the measurement template (Fig. 3).
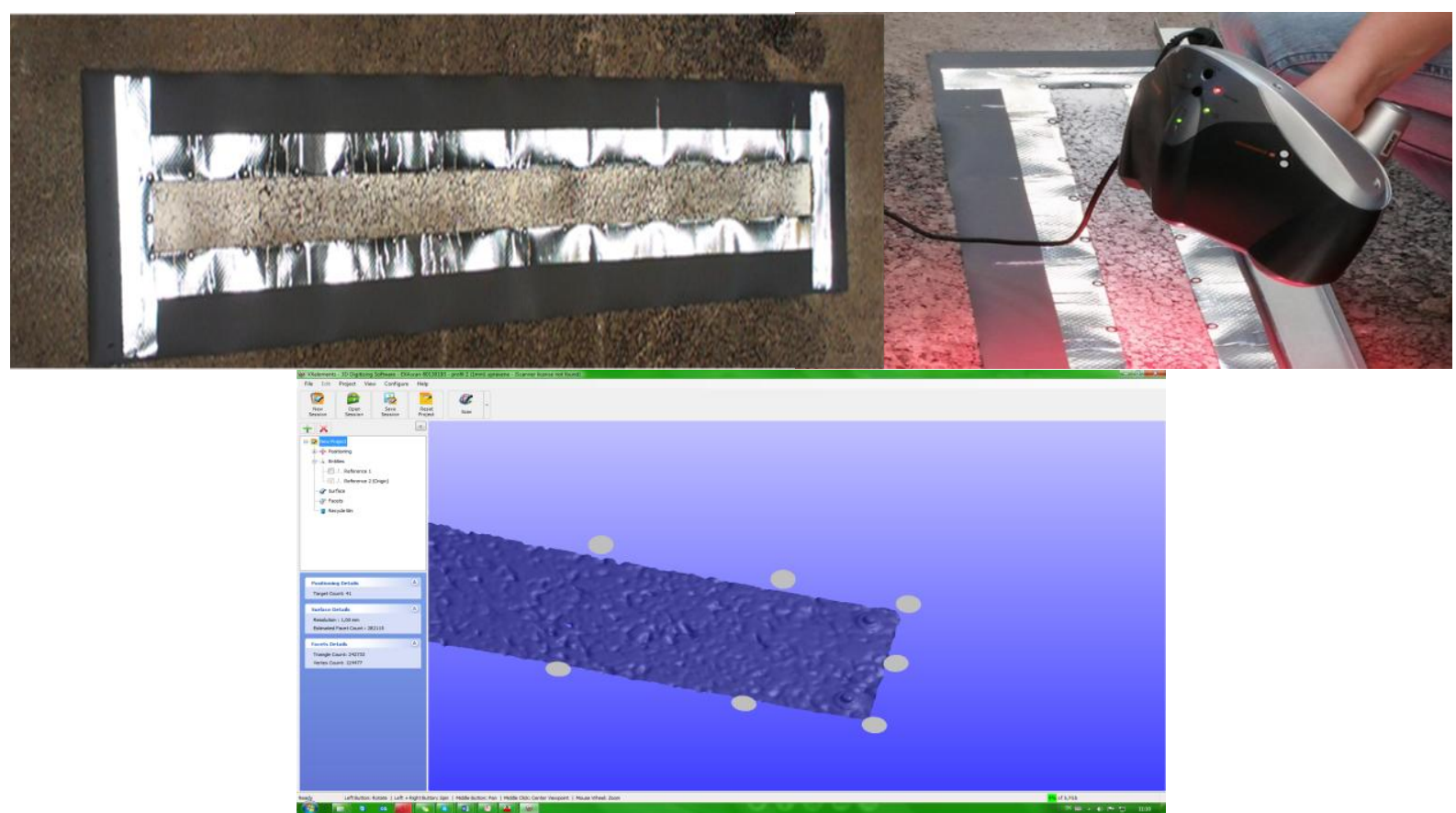

Fig. 4: Template bordering the observed cross-section with analyzing the surface SW "VXelements".

The schema on Fig. 4 shows one of the evaluations of the cross-section on the test field. As it is immediately obvious, the transverse unevenness is not present, or more precisely intercepted unevenness is inappreciable value.
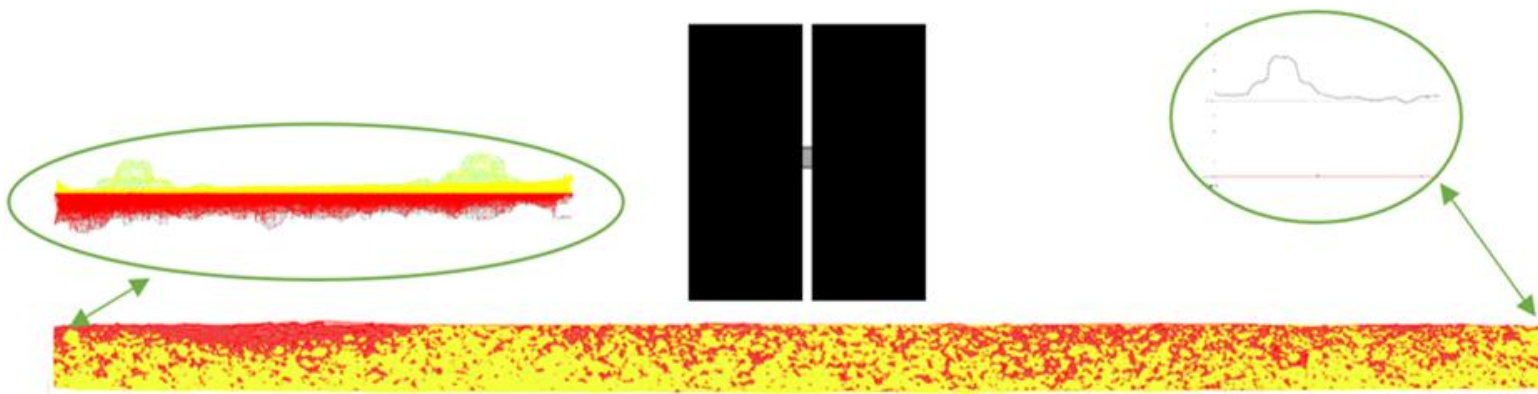

$1600 \mathrm{~mm}$

Fig. 5: Scanned cross-section of the analyzed road. 
During the detailed and enlarged view of the edge of the profile, there are evident nails, which have their legitimate role in repeated measurements and will serve as permanent points through which it will be possible to measure an identical profile in any timeframe. In the middle of the profile, there is shown a double axle, which simulates the real effects of crossover of the truck on the experimental field (Fig.5). Our priority effort will monitor changes in the surface properties of the pavement after a defined amount of axle loads. On the ground of this data, there will be then possible to determine the functions that will predict the development of analyzed serviceability parameters of pavement's surface, depending primarily on the traffic load [9].

\section{Analyzing of measuring data - GPR measurement}

The before mentioned test field was investigated by the GPR system SIR-20 (GSSI) in a 3D alignment. In this study, antenna, with center frequency of $1 \mathrm{GHz}$ was applied. The step of measurement of $0.01 \mathrm{~m}$ was used in these cases. The time record length differs, $20 \mathrm{~ns}$ were used for $1 \mathrm{GHz}$ antenna. The total measured length of the profile was $1.4 \times 2.6 \mathrm{~m}$ with $0.2 \mathrm{~m}$ grid spacing. Manufacturer's specified depth range for this type of antenna is about $0.9 \mathrm{~m}$ for $1 \mathrm{GHz}$, which is sufficient for diagnosing of road condition and construction layers. Radargram was treated by special software package ReflexW and Radan 7.0.

The raw data were firstly processed in the following manner; 1 Static correction - setting of the 0 value (the surface of the test field); 2 1D filtration - background; 3 Car-box filtration; 4 Selective amplification of the signal. Results are represented by a series of 2D radargram interpretations (Fig. 6).
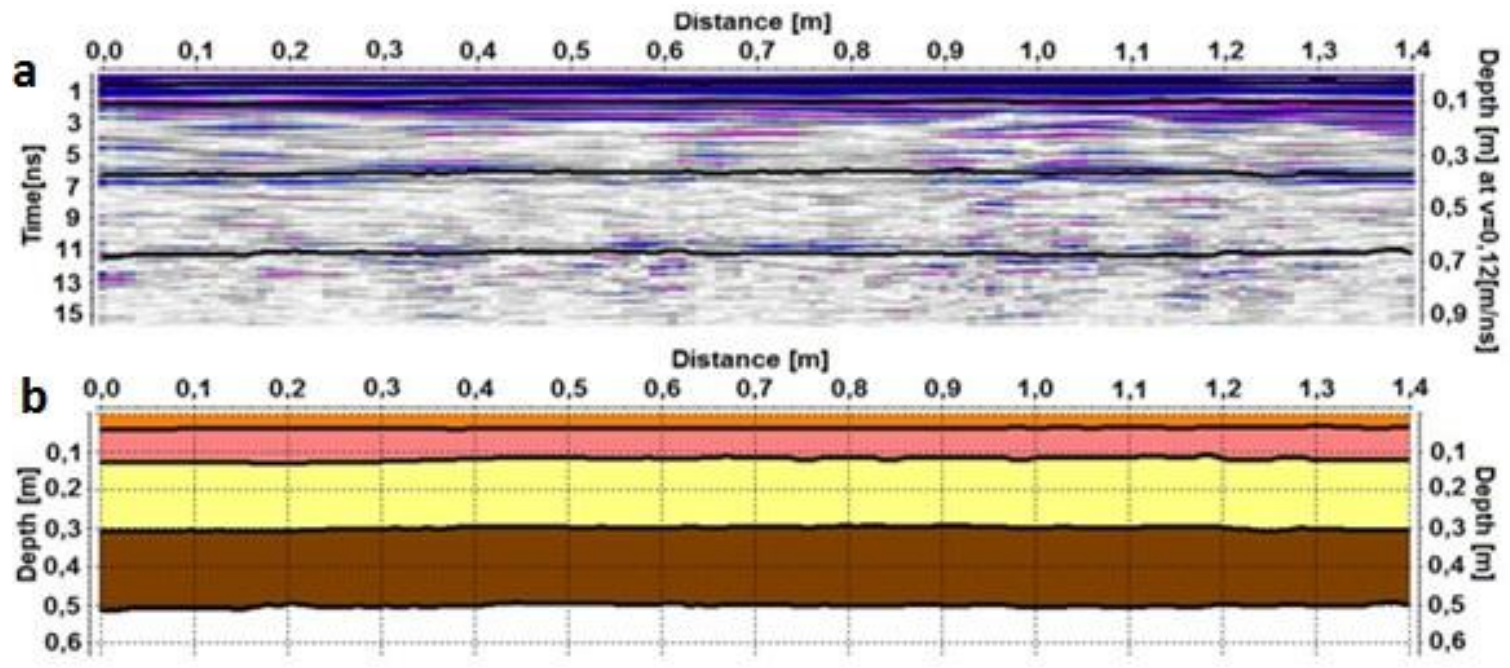

Fig. 6: a) The resulting radargram obtained by $1 \mathrm{GHz}$ antenna. The black line indicates boundaries between the layers of the test field. b) The resulting depth section of the test field.

The before mentioned 2D interpretations were carried out for identification of the test field layers. These two profiles are perpendicular to the drive way (axial load) of the test field device. Considering the constructing layers of the pavement, both antennas show similar results but different values for dielectric constants. The treated radargrams was converted to depth section after the raw data processing. Every pavement interface was determined by analysis of the amplitude in the time travel section (Fig. 2 a) and Fig. 4 a) and on this basis it was converted into the final depth section (Fig. 2 b) and Fig. 4 b). The resulting GPR interpretation of the test field is almost identical with the project documentation. There can be observed intact subhorizontal layers of the experimental road section. 


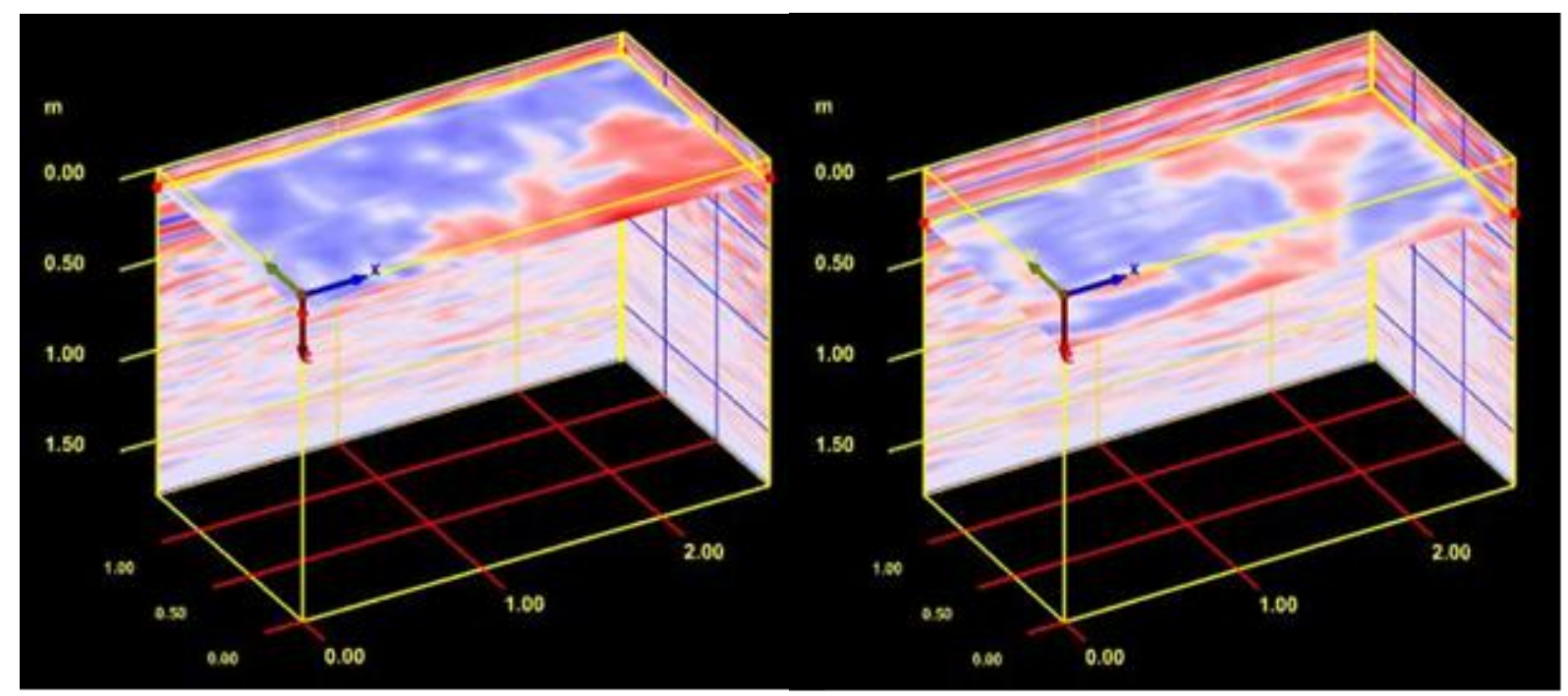

a)

b)

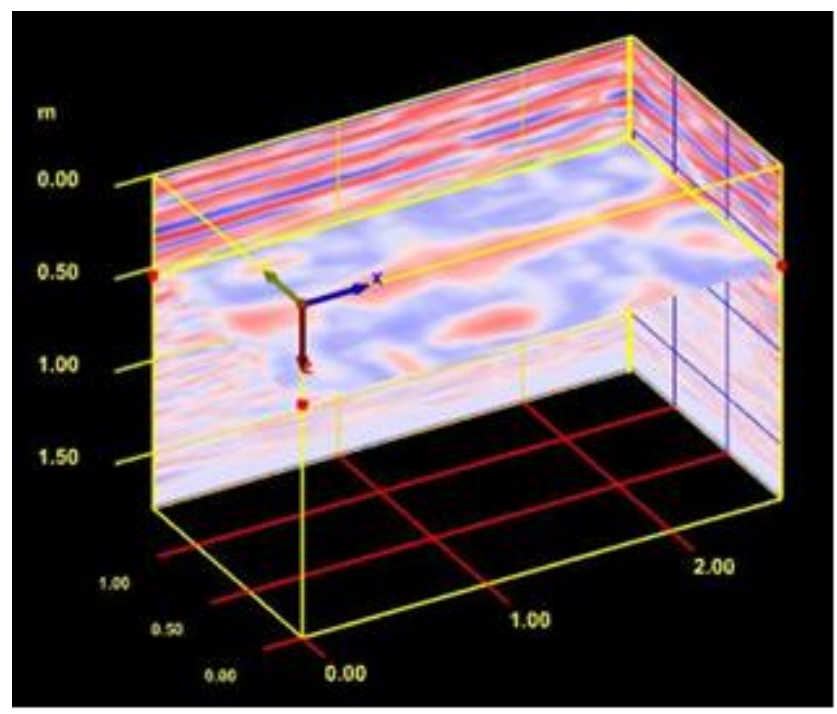

c)

Fig. 7: 3D visualization of GPR results at different depth levels: a) $0.1 \mathrm{~m}, \mathrm{~b}) 0.3 \mathrm{~m}, \mathrm{c}) 0.54 \mathrm{~m}$.

Results based on interpretation of measurements carried out with $1 \mathrm{GHz}$ antenna show three of four layers. The very first one cannot be distinguished, which might be caused by the lower sensitivity of the $1 \mathrm{GHz}$ antenna on very shallow anomalies. Both interpretations, 2D as well as 3D, show subhorizontal layers which are not disrupted or bend. This result was expected because the test field is very new. All layers appear to be subhorizontal without disruption or bend. Degradation of the pavement can be expected in future, when the axial load will be applied in many cycles. This degradation should be also observed in the radargrams.

Despite of above mentioned, methods of GPR have not yet become a standard tool for the road administrators in the diagnosis and maintenance of roads. It is also obvious that these methods, when they are used in proper manner, can save some financial expenses in pavement management processes.

\section{Rut depth}

Except the monitoring of the pavement's roughness and texture our research center also realizes the measurement of transverse unevenness. The evaluation of road evenness in transversal direction consists in measurement of transverse evenness as aberrance from theoretical plain. From this reason is the terminology crucial to differentiate these two basic terms. Transverse road evenness is unevenness of road surface in vertical direction on the traffic direction. It expresses as the difference between existing and theoretical transversal profile of road. The measurement and 
evaluation of transverse evenness is realized because of determination quality of pavement's surface from the aspect of permanent deformations, which are well-known as road rut [1].

By measurement of transverse evenness are valuating these parameters:

- rut depth /RD/ - vertical distance between connection of apex wave and the lowest point of wave,

- permanent deformations /PD/ -vertical distance between first and last point of measured profile and the lowest point of wave (Fig. 8),

- water depth /WD/ - vertical distance between horizontal flat ground in the position the lowest point of wave and the lowest point of wave (Fig. 8).
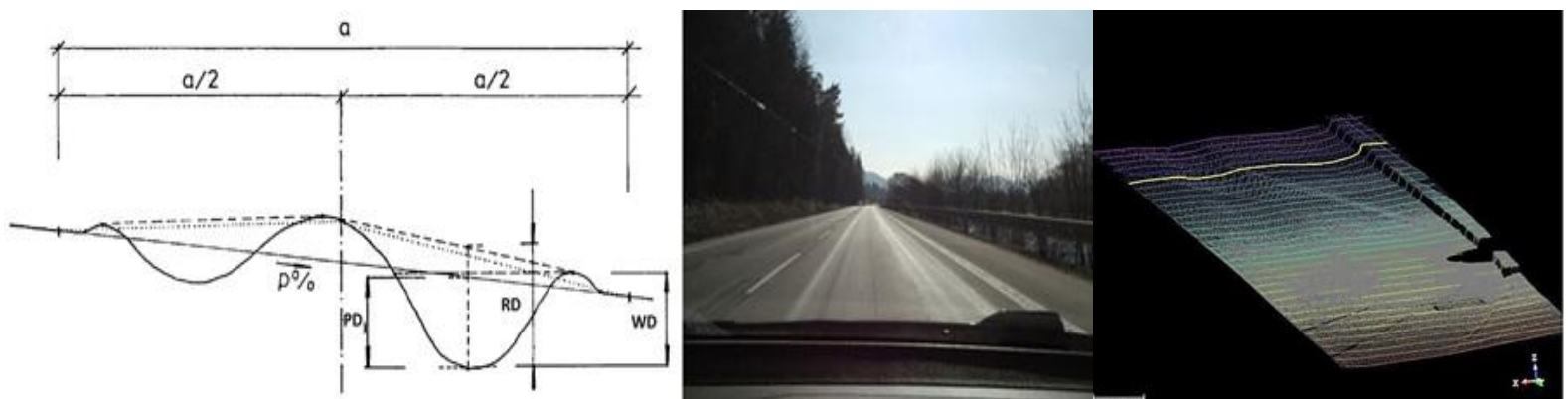

Fig.8: Elementary characteristics of transverse evenness, pavement rut in traffic lane and monitored rut on the testing field.

The creation of road ruts (Fig. 8) is as a result of mostly two dominant aspects; in first case overlimited traffic load and excessive traffic density and in second case parking and staying heavy trucks on unassimilated pavement's surface - especially inappropriately elected surface [2]. From this reason is very helpful to use the testing field to develop for more detail the reason of creation of road ruts. (Fig. 8).

\section{Conclusions}

One of the most important and the most significant factors which directly influences economic factors, as well as safety traffic on the roads is a parameter of serviceability. It is important not only from the perspective of properly elected maintenance, reconstruction, or planned road restoration. Constant road's monitoring and analyzing helps overall diagnostics of the road network.

This article introduces basic characteristics and two important parameters of serviceability skid resistance and transverse unevenness. It also points out on the necessity of the further monitoring and analyzing the above mentioned parameters. They will create features and models that will later play an important role in the future predictions and thereby directly help to develop and attempt to improve our road network.

Our primary objective is an application of developed degradation models in a unified comprehensive manual for pavement administrators so applicable use of the acquired results in practice.

\section{Acknowledgement}

The research is supported by European regional development fund and Slovak state budget by the project "Research centre of University of Žilina", ITMS 26220220183.

\section{References}

[1] ČELKO, J. et al. : The surface properties of pavements, in Slovak: Povrchové vlastnosti vozoviek (Prevádzková spôsobilost' vozoviek), EDIS Žilina, 2000. ISBN 80-7100-774-9.

[2] DECKÝ, M. - DRUSA, M. - PEPUCHA, L'., - ZGÚTOVÁ, K.: Earth Structures of Transport Constructions. Pearson Education Limited 2013, Edinburg Gate, Harlow, Essex CM20 2JE. Edited 
by Martin Decký, p. 180, ISBN 978-1-78399-925-5. Printed and bound in Great Britain by Ashford Colour Press, Gasport, Hampshire.

[3] DECKÝ, M. - GAVULOVÁ, A. - PITOŇÁK, M. - PUTIRKA, D. - VANGEL, J. - ZGÚTOVÁ, K.: Designing and budgeting asphalt pavements, in Slovak: Navrhovanie a rozpočtovanie asfaltových vozoviek, BTO print, Žilina 2010, ISBN 978-80-970388-0-9.

[4] DRUSA, M. - DECKÝ, M. et al.: Navrhovanie a kontrola zemných konštrukcií dopravných stavieb. Vedecká monografia, vydavatel'stvo ŽU - EDIS, 2013, s. 522, ISBN 978-80-554-0823-1.

[5] KOVÁČ, M. - REMIŠOVÁ, E. - ČELKO, J. - DECKÝ, M. - ĎURČANSKÁ, D.: Diagnostics of pavement's serviceability parameters, In Slovak: Diagnostika parametrov prevádzkovej spôsobilosti, Žilinská univerzita v Žiline, EDIS, 2012, ISBN 978-80-554-0568-1.

[6] KOTEK, P. - SLABEJ, M..: Using of 3D Road Surface Model for Monitoring of Transverse Unevenness and Skid Resistance/XXIII. Russian-Polish-Slovak Seminar s medzinárodnou účastou „Theoretical Foundation of Civil Engineering /Teoretické základy stavebného inžinierstva/“, Wroclaw (Szklarsa Poręba), Poland, ISBN 978-80-554-0915-3, p. 30.

[7] MIKOLAJ, J. et al.: Vývoj technológie akcelerovaného testovania vozoviek $\mathrm{v}$ rámci výskumného centra Žilinskej university, In: RESEARCH FORUM 2014 na tému [elektronický zdroj] : štrukturálna pomoc EÚ pre výskum a inovácie - efekty, príležitosti a riziká : zborník prednášok z medzinárodnej vedeckej konferencie : Grand Hotel Bellevue Vysoké Tatry, 9.-11. apríla 2014. Žilina: Výskumné centrum Žilinskej univerzity v Žiline, 2014. - ISBN: 978-80-554-0842-2.

[8] MIKOLAJ, J. - SCHLOSER, F. - REMEK, L'.: Life-cycle cost analysis in pavement management system/Analýza nákladov životného cyklu stavieb $\mathrm{v}$ systéme hospodárenia $\mathrm{s}$ vozovkou. In: Communications - scientific letters of the University of Žilina. 2013, Volume 15, No. 3, pp.

[9] PŘIKRYL, M. - KUTIL, L. - ŽÁK, J.: 3D measurement technology of laser scanning, in Czech: 3D měření technologií laserového skenování, Švédsko, silnice 41 (väg 41) Bergham-Gullberg. Conference Asfaltové vozovky 2011, České Budějovice, 77-81.

[10] SIVANSWARAN, N - PIERCE, L.M. - MAHONEY, J.P.: Transition from Manual to Automated Pavement Condition Surveys, Washington State's Experience, 6th International Conference on Managing Pavements, 2004. 